Dijana Vuković*

Ivana Mamić Sačer ${ }^{* *}$
JEL Classification L33, M40, P51

Preliminary statement

\title{
THE IMPACT OF PRIVATISATION PROCESS ON BUSINESS PERFORMANCE OF THE SELECTED COMPANIES IN THE REPUBLIC OF CROATIA
}

Privatisation processes have begun in the last decades of last century. Many countries recognized the advantages of privatisation in the form of financial goals such as increasing state budget, lowering indebtedness and strengthening market economy. Furthermore, the presumption of privatisation is that private ownership is better for achieving higher profitability of a company. Financial statements are common expression tools for companies' business performance and financial position. Since accounting information system is a system where business events should be recorded, main output of the system are basic financial statements. The main goal of this study was to investigate the impact of privatisation process on business performance on the example of the selected companies in the Republic of Croatia. For the purpose of the study, the theoretical analysis of privatisation effects on business performance was made. Other than that, the empirical analysis of the selected companies in Croatia was conducted. This analysis was performed in two ways. First, the analysis of the selected financial ratios before and after the privatisation process was done through quartile analysis. The observed financial ratios were gross profit margin, ROA, ROE, total assets turnover and total economy ratio. To gain the individual impact of the privatisation process a deeper analysis of the selected ratios was conducted on

* I. D. Vukovic, Ph.D., Assistant Professor, Faculty of Economics, University of Bihać, Bosnia and Herzegovina (E-mail: dijana.vukovic@unbi.ba).

** I. Mamić Sačer, Ph.D., Full Professor, Faculty of Economics and Business, University of Zagreb (E-mail: imamic@efzg.hr).

The paper was received on May 8th, 2018. It was accepted for publication July 17th, 2018. 
the same research sample. Research results based on quartile analysis indicated that there is a difference between profitability prior and after privatisation and the privatized companies are more successful than the observed state-owned companies. However, based on the individual analysis' research results the hypothesis that privately owned companies are more successful than the state-owned companies is only partially confirmed.

Keywords: business performance, privatisation, state-owned companies, private companies, Croatia

\section{Introduction}

Financial statements are common expression tools for companies' business performance and financial position. Since accounting information system is a system where business events should be recorded, main output of the system are basic financial statements. State-owned and private companies constitute an important part of economy and public sector. There is a common presumption that private companies are more efficient than private companies. This is due to the fact that a privatised subject operates in the environment of strong competition. In that case, there is a pressure for companies to perform well. The aim of the paper is to investigate the impact of privatisation process on business performance of the companies in the Republic of Croatia. For the purpose of the study, the theoretical analysis of privatisation effects on the business performance was made. Other than that, the empirical analysis of the selected companies in Croatia was conducted. This analysis was performed in two ways. First, the analysis of the selected financial ratios before and after the privatisation process was done through quartile analysis. To gain the individual impact of the privatisation process a deeper analysis of the selected ratios was conducted on the same research sample.

\section{Theoretical presumptions of privatisation effects on business performance}

Privatisation can be defined as "transfer by central or local government of a business and its assets from state to private ownership" (ISSAI, 1998). First privatisation projects worldwide have started in USA and Canada and after that the trend has broadened on European countries. The end of 80-ies and the beginning of 90 -ies of last century has been marked with large impact of privatisation pro- 
cess (Akrap, 2009). According to the Law on privatisation (1996) in Croatia, privatisation is a part of economic and developing strategy and policy of the Republic of Croatia and it is conducted in order to achieve faster economic growth, productive employment maintenance and generation of new work places, technology modernisation of Croatian economy, the encouragement of entrepreneurship etc.

Certain research results have shown that that "state-owned enterprises with private sector ownership have higher levels of performance than those fully owned by the government" (Astami, 2010). In that favour, there is an opinion that managers in public sector "have little personal incentives to improve operational performance" (Kawabata, 2006) Also, Megginson and Netter (2001) emphasize that privatization "works in that the firms become more efficient, more profitable, and financially healthier, and reward investors". However, Simeon and Murrell (2002) argue about such clear effect of privatisation in transition economies.Other than that, a study in Belarus has found that privatization have no significant effect on company performance (Estrin, 2006). Further to these results and general presumptions on privatisation positive effects on business performance, the main goal of our research was set. We wanted to explore the impact of privatisation on business performance of companies in Croatia.

Previous research results in Croatia were focused on the investigation of total income and/or solvency of state-owned and private companies when analysing efficiency of such groups of companies (Čulo, 2012). Further, the business success between state-owned and private companies is not rarely identified with productivity of a company on the state level where the special attention to individual company is not given. (Vizek, 2015). The analysis of the abovementioned previous research indicates that individual analysis prior and after the privatisation process based on companies financial statements has not often been in the focus of research. Taking into consideration such information, the research tasks were set: to make financial statements analysis and use financial ratios in order to examine the impact of privatisation on the business performance of companies in Croatia.

Two main criteria for companies' evaluation are commonly used. That are financial position and business performance. Business performances represent companies' efficiency primarily based on profit and loss account. However, for the financial ratios' calculation, sometimes, the items from balance sheet should be used as well. Further, business performance of a company could be evaluated by cash flow analysis, too. There are many reasons that could affect company's business performance. Industry type, a company size, management effectiveness, business environment, market prices, cost effectiveness and profit margins etc. are some of the reasons. When it comes to business performance measurement there are certain blocks of ratios usually used for such measurement. Those are: activity, economy, profitability and investment ratios (Žager, 2017). Other than that, one 
can use certain financial ratios based on cash flow in order to gather information on company's efficiency. Carlaw \& Mills (1991) offer following block of ratios based on cash flow statements: earnings quality ratios, capital acquisition ratios and cash flow return ratios. These blocks supplement traditional performance measures based on P\&L.

\section{Empirical research on business performance of state-owned and private companies in the Republic of Croatia}

\subsection{Description of research model}

Main research question is to find out is the business performance of the privatised companies higher than its performance before the privatisation process. The basis for the selection of companies was State Audit Office's report on the conducted privatisation audit in the period of 2001-2004. 287 privatised companies were included in the report. The research was conducted based on the financial statements of 50state-owned companies in the period of 1992-2002. The research was limited with available data for all three following years. Since there isn't available data for all companies, a company was included in the research provided financial data is published for at least one year before and after the privatisation. Due to the limitation of certain financial data which should be included in the financial ratios' calculation, the sample has the feature of unbalanced panel sample.

Two parts of the research were conducted.

First, the selected financial ratios were calculated for three following years before and after privatisation. That is, the comparative analysis was done for every company in the sample. We compared the financial ratios calculated for each company while it was state-owned to the ratios of private companies.

The selected financial ratios include the evaluation of profitability, economy and activity of a company. Tools used in the research are:

- Gross profit margin = (profit before taxation + interests) $/$ total income,

- ROA i.e. return on assets $=($ profit before taxation + interests $) /$ total assets,

- ROE i.e. return on equity =profit before taxation / equity,

- Total assets turnover = total income / total assets,

- Total economy ratio = total income $/$ total expenses. 
D. VUKOVIĆ, I. MAMIĆ SAČER: The impact of privatisation process on business performance of the selected...

EKONOMSKI PREGLED, 69 (6) 621-637 (2018)

\subsection{Testing the impact of privatization on business performance - quartile analysis}

The analysis was conducted in a way that for each company the performance of the company's business before and after the privatization period was assessed. The analysis was done based on five financial indicators. Further, in order to determine the differences, the assessed business performance of each company was compared to each other. In order to determine the performance of a company's business, it was necessary first to express the financial indicators in the modalities, and for that purpose, in the first step, to calculate quarters of each indicator for all the observed years together. Quartiles are values where a population is divided into four equal groups. Each group is constructed according to the distribution of financial ratios (profitability, activity and economy). However, by looking at the indicators together, the level of business performance of each company has been gained.

Thus, quartiles were calculated, i.e. 1st and 3rd quartile and median, based on the value of each financial indicator. Then, based on the calculated quartiles, four different intervals were determined and the companies were given points from 1 to 4 depending on the interval, based on the value of the financial indicators. Point 1 is awarded if the company has the value of financial indicators which puts the company in the first interval and so on, where 1 indicates a highly unprofitable, inactive and non-economic business, while 4 indicates the profitable, active and economic business of the company.

The quartile values for financial indicators of profitability are shown in the Figure 1.From the chart it is apparent that the values of the 1st quartile and the median for the selected financial indicators of profitability are negative, meaning that $50 \%$ and fewer companies were unprofitable. 


\section{Figure 1.}

\section{QUARTILE VALUES FOR FINANCIAL INDICATORS OF PROFITABILITY IN THE PERIOD 1992-2002}

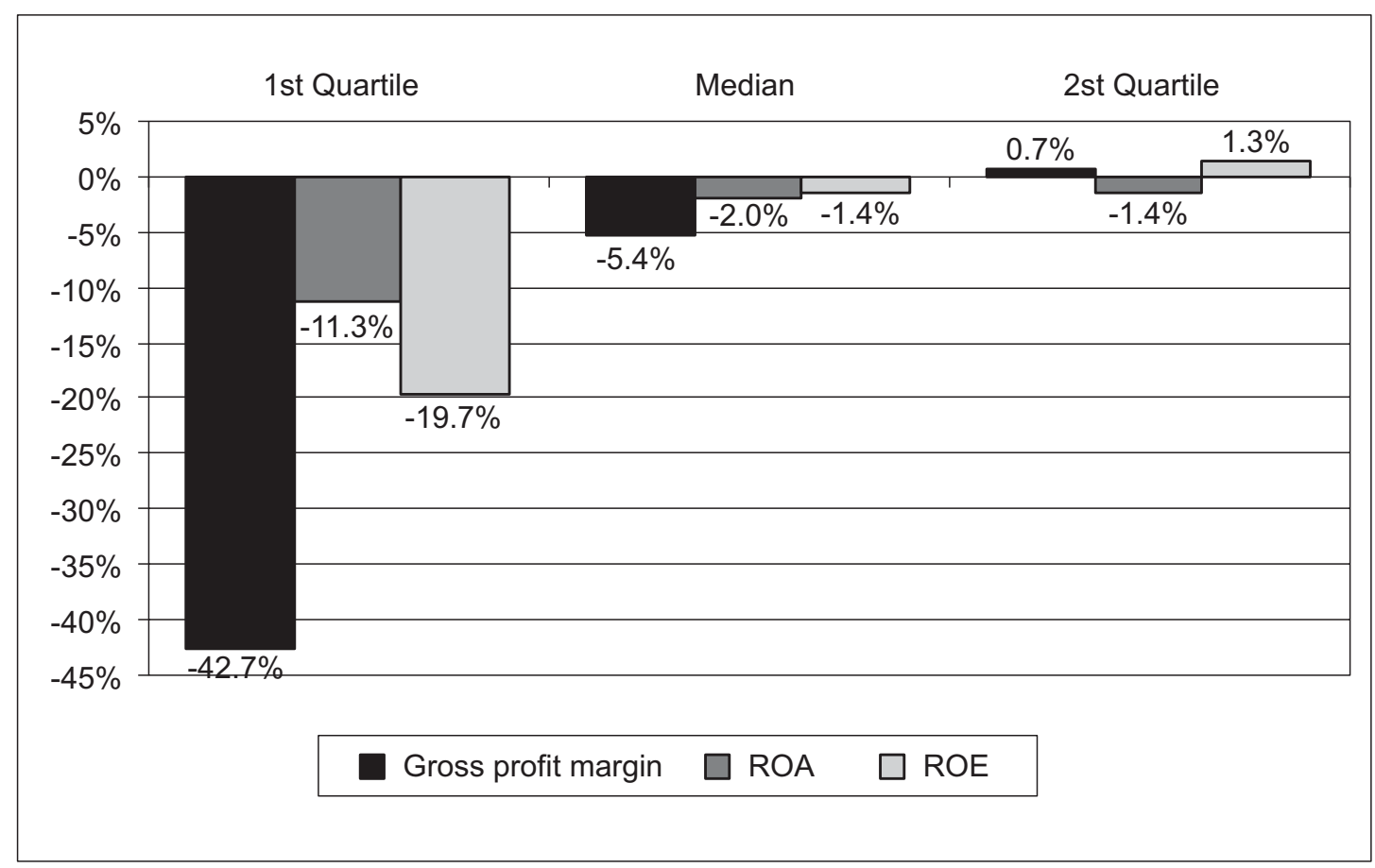

Source: Creation of authors

Quartile values for financial indicators of activity and economy are shown in the table 1 below.

Table 1 .

\section{QUARTERLY VALUES FOR SELECTED FINANCIAL INDICATORS}

\begin{tabular}{|c|c|c|c|}
\hline Financial ratios & 1st Quartile & Median & 2nd Quartile \\
\hline Total assets turnover & 0,1593 & 0,5123 & 1,0761 \\
\hline Total economy ratio & 0,7089 & 0,9492 & 1,0082 \\
\hline
\end{tabular}

Source: Creation of authors

Based on the quartile values of each financial indicator, the intervals with the appropriate points are determined, as shown in the table 2 below. 
D. VUKOVIĆ, I. MAMIĆ SAČER: The impact of privatisation process on business performance of the selected... EKONOMSKI PREGLED, 69 (6) 621-637 (2018)

Table 2.

\section{DISPLAY OF THE INTERVAL BOUNDARIES BASED ON THE VALUES OF THE FINANCIAL INDICATORS}

\begin{tabular}{|c|c|c|c|c|}
\hline & \multicolumn{4}{|c|}{ The boundary intervals and corresponding points } \\
\hline $\begin{array}{c}\text { Financial } \\
\text { ratio }\end{array}$ & $\mathbf{1}$ & $\mathbf{2}$ & $\mathbf{3}$ & $\mathbf{4}$ \\
\hline $\begin{array}{c}\text { Gross } \\
\text { profit } \\
\text { margin }\end{array}$ & $\mathrm{GPM} \leq-42,65 \%$ & $-42,65 \%<\mathrm{GPM} \leq-5,42 \%$ & $-5,42 \%<\mathrm{GPM} \leq 0,70 \%$ & GPM $>0,70 \%$ \\
\hline ROA & $\mathrm{ROA} \leq-11,27 \%$ & $-11,27 \%<\mathrm{ROA} \leq-2,00 \%$ & $-2,00 \%<\mathrm{ROA} \leq 0,47 \%$ & $\mathrm{ROA}>0,47 \%$ \\
\hline ROE & $\mathrm{ROE} \leq-19,70 \%$ & $-19,70 \%<\mathrm{ROE} \leq-1,40 \%$ & $-1,40 \%<\mathrm{ROE} \leq 1,25 \%$ & ROE $>1,25 \%$ \\
\hline $\begin{array}{c}\text { Total } \\
\text { assets } \\
\text { turnover }\end{array}$ & TAT $\leq 0,1593$ & $0,1593<\mathrm{TAT} \leq 0,5123$ & $0,5123<\mathrm{TAT} \leq 1,0761$ & TAT $>1,0761$ \\
\hline $\begin{array}{c}\text { Total } \\
\text { economy } \\
\text { ratio }\end{array}$ & TER $\leq 0,7089$ & $0,7089<\mathrm{TER} \leq 0,9492$ & $0,9492<\mathrm{TER} \leq 1,0082$ & TER $>1,0082$ \\
\hline
\end{tabular}

Source: Creation of authors

Once the intervals are set, based on the value of the financial indicators, each company is assigned the appropriate point for each indicator in each year. For example, if a company had the value of total assets turnover coefficient of 0.6555 in a given year, then it is awarded with point 3.

However, in order to assess the overall business performance of a company, it is necessary to look at all the indicators collectively. For this purpose, the degree of performance of each company was estimated, which was calculated as a weighted average with the same weighting values. In other words, the total degree of performance is calculated according to the following formula:

$$
S U=\sum_{i=1}^{5} p_{i} \times w_{i}
$$

where $\mathbf{S U}$ is the overall degree of performance, pi is assigned point based on the value of the financial indicator, while wi is weighted. For most companies there is data for each financial indicator, so the weight will be w1 $=\mathrm{w} 2=\mathrm{w} 3=\mathrm{w} 4=\mathrm{w} 5=$ 0,20 . In the case that there is no data for a particular company, the weight will be equal to the number of indicators for which there is a data. 
Based on the abovementioned, the level of business activity before privatization and after privatization is calculated, and the results, together with the values of the medians, are given in the table 3 and in the figure 2.

Table 3.

MEDIAN VALUE AND PERFORMANCE LEVEL BEFORE AND AFTER PRIVATIZATION

\begin{tabular}{|c|c|c|}
\hline & $\begin{array}{c}\text { Median (before } \\
\text { privatization) }\end{array}$ & $\begin{array}{c}\text { Median (after } \\
\text { privatization) }\end{array}$ \\
\hline Total assets turnover & 0,3844 & 0,3700 \\
\hline Total economy ratio & 0,9163 & 0,9340 \\
\hline PERFORMANCE LEVEL BEFORE PRIVATIZATION & \multicolumn{2}{|c|}{$\mathbf{2 , 2 9}$} \\
\hline PERFORMANCE LEVEL AFTER PRIVATIZATION & \multicolumn{2}{|c|}{$\mathbf{2 , 4 5}$} \\
\hline
\end{tabular}

Source: Creation of authors

Figure 2.

COMPARISON OF MEDIAN VALUES FOR FINANCIAL INDICATORS OF PROFITABILITY BEFORE AND AFTER PRIVATIZATION

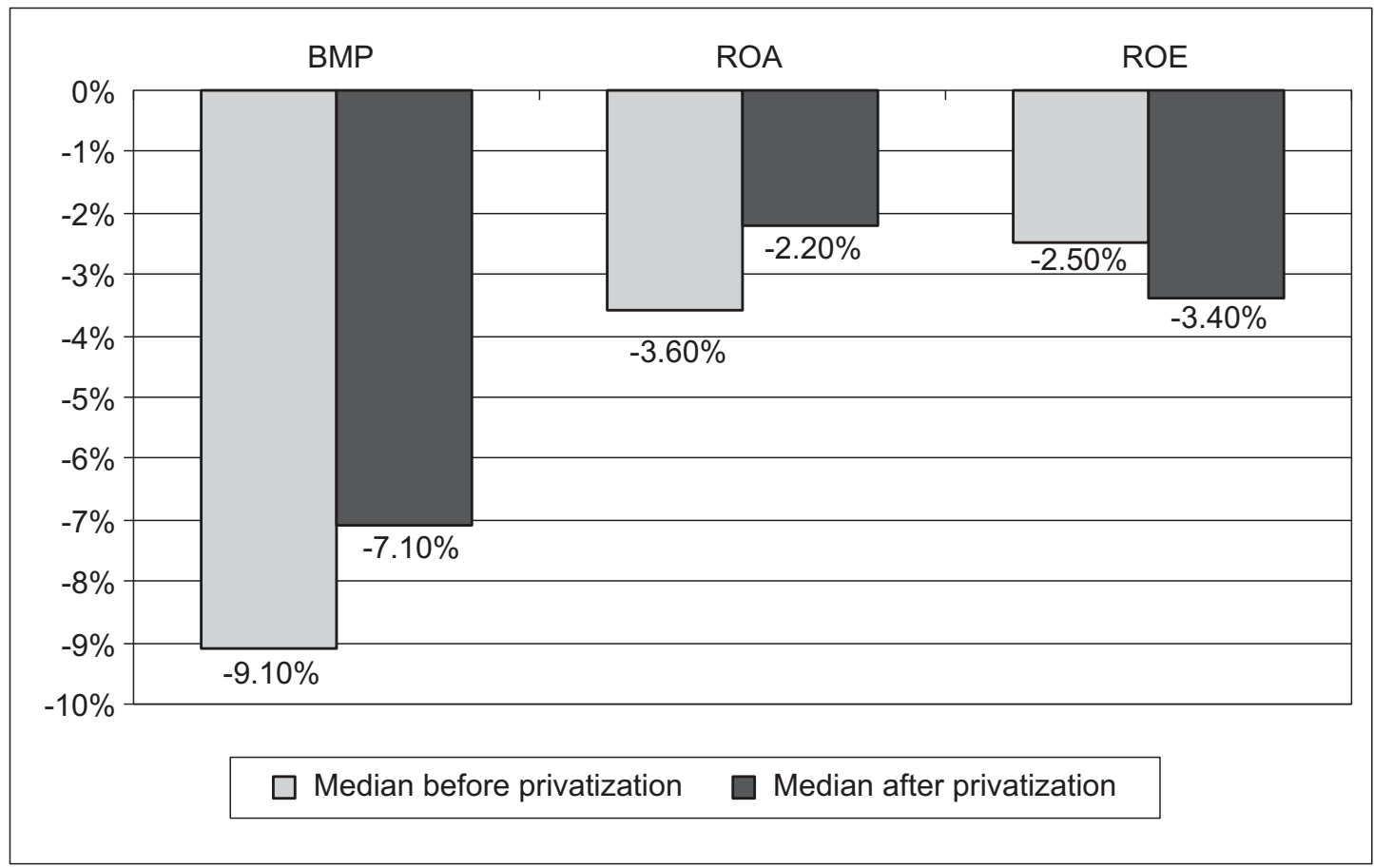

Source: Creation of authors 
Before analysing the results in table 3 and in figure 2 it should be noted that it is desirable that indicators of profitability are, above all, positive and higher. If they are negative, this indicates that the company is operating with a loss. Furthermore, it is desirable that the activity indicator is also as large as possible, while the economic indicator should be greater than 1, otherwise the company will operate with a loss. Similarly, business operations are more successful if the calculated rate of the performance is higher. As is apparent in the results, the median of the selected financial indicators as well as the level of performance is greater, i.e. less negative in the period after privatization, pointing out that after privatization companies have improved their business. However, looking at the given values, it cannot be said that the privatized companies are successful since, even after privatization, a considerable number of businesses were operating with a loss. Still, it shows that they are more successful than public companies.

Furthermore, t-test difference analysis was conducted in order to investigate if there is statistically significant difference in the observed values. The t-test results are shown in the table 4 below.

Table 4.

RESULTS OF THE T-TEST

\begin{tabular}{|c|c|c|c|c|}
\hline \multicolumn{2}{|c|}{} & Average & Sample size & $\begin{array}{c}\text { Standard } \\
\text { deviation }\end{array}$ \\
\hline \multirow{2}{*}{ Performance level } & Before privatization & 2,2900 & 51 &, 86100 \\
\cline { 2 - 5 } & After privatization & 2,4504 & 51 &, 94350 \\
\hline $\begin{array}{c}\text { Estimated average } \\
\text { difference }\end{array}$ & Standard deviation & t-test & $\begin{array}{c}\text { Degrees of } \\
\text { freedom }\end{array}$ & p-value \\
\hline $\mathbf{- 0 , 1 6 0 3 9}$ & 0,72625 & $-1,777$ & 50 & 0,041 \\
\hline
\end{tabular}

Source: Creation of authors

Since it is assumed that the level of performance of public companies, i.e. companies before the privatization, is lower than the level of performance of privatized companies, a one-way test is carried out at the lower limit. As it can be seen from the test results, test size of the t-test is -1.777 , while the corresponding $\mathrm{p}$-value is 0.041 .Accordingly, and since the p-value is less than the theoretical level of significance of 5\%, the null hypothesis of equality of the middle is rejected and it is concluded that there is a difference between profitability prior and after privatisation and the privatized companies are more successful than the observed public 
companies. However, given that the circumstances of privatization influenced the business results of those companies, the research restrictions are related to those circumstances.

\subsection{Individual business performance testing on the selected privatised companies - results and discussion}

In order to eliminate the influence of grouping into quartile, an individual analysis was performed for each company. The analysis was conducted in a way that for each company the business performance was evaluated in the three years before and three years after the privatization, based on the data of previously presented financial indicators. After that, a three-year average of each indicator was calculated for the period before and after privatization (Vuković, 2016). The results were tested by a hi-squared test to evaluate the frequency of changes in the analysed indicators. 


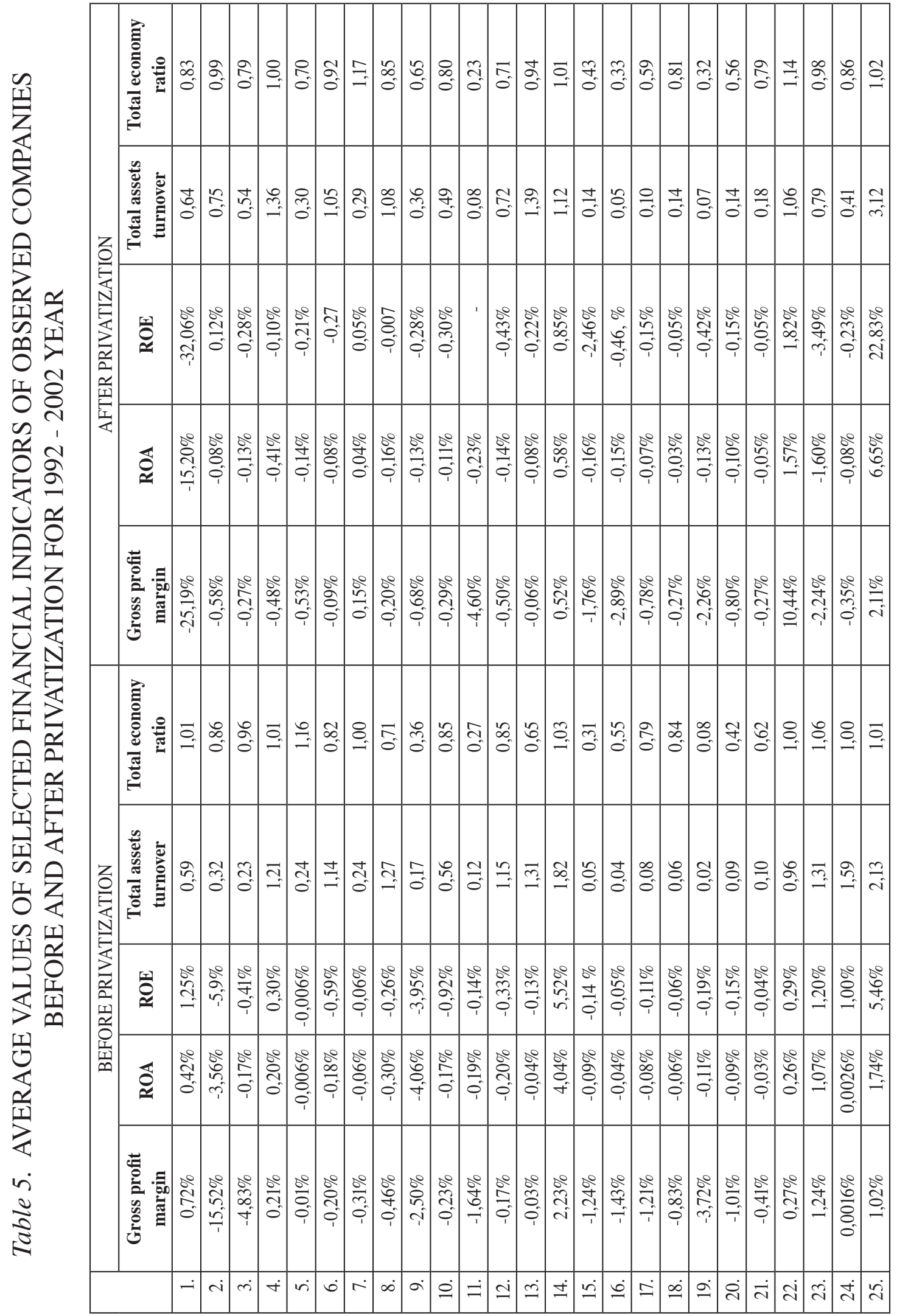




\begin{tabular}{|c|c|c|c|c|c|c|c|c|c|c|c|c|c|c|c|c|c|c|c|c|c|c|c|c|c|}
\hline \multirow{5}{*}{ 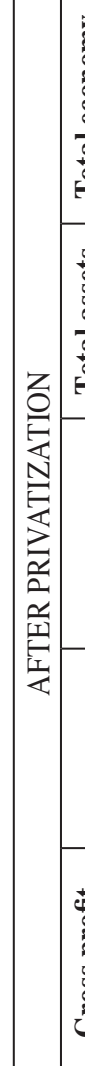 } & 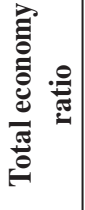 & $\begin{array}{c}\tilde{\sigma} \\
- \\
-\end{array}$ & $\underset{-}{-}$ & $\stackrel{f}{=}$ & s.a. & $\stackrel{8}{-}$ & $\begin{array}{l}\infty \\
\infty \\
0 \\
0\end{array} \mid$ & $\begin{array}{l}0 \\
0 \\
0 \\
0\end{array}$ & $\stackrel{\vec{\sigma}}{-}$ & $\tilde{\sigma}$ & ฮै & ठे. & & $\underset{-}{\stackrel{\Xi}{-}}$ & $\begin{array}{l}\vec{\infty} \\
0 \\
0\end{array}$ & & $\begin{array}{c}\sigma_{-} \\
-\end{array}$ & & $\begin{array}{c}n \\
0 \\
0\end{array}$ & 8 & $\stackrel{\sigma}{-}$ & $\vec{\sigma}$ & $\underset{-}{+}$ & $\begin{array}{l}n \\
2 \\
2\end{array}$ & \\
\hline & 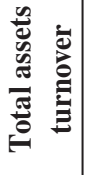 & $\frac{\infty}{0}$ & $\begin{array}{l}\overline{0} \\
0\end{array}$ & $=$ & ०. & $\begin{array}{l}\infty \\
2 \\
0 \\
0\end{array}$ & ले & $\stackrel{0}{\circ}$ & 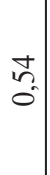 & $\bar{m}$ & : & है & $\begin{array}{l}2 \\
0 \\
0 \\
0\end{array}$ & $\stackrel{m}{=}$ & $\begin{array}{l}\circ \\
\vdots \\
0\end{array}$ & $\begin{array}{ll}= & 1 \\
0 & 0\end{array}$ & $\begin{array}{c}\bar{b} \\
0\end{array}$ & \begin{tabular}{c|c}
$t$ \\
0 \\
\end{tabular} & 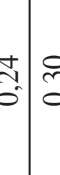 & co & 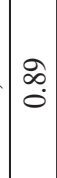 & $\begin{array}{l}\tilde{Z} \\
=\end{array}$ & $\stackrel{+}{\rightarrow}$ & oे & \\
\hline & 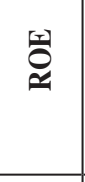 & $\begin{array}{l}\circ \\
\frac{0}{0} \\
0\end{array}$ & 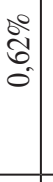 & $\frac{\circ}{0}$ & 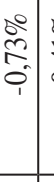 & $\begin{array}{l}00 \\
\overline{7} \\
1 \\
1\end{array}$ & $\begin{array}{l}0 \\
0 \\
0 \\
0 \\
1\end{array}$ & 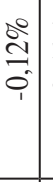 & $\begin{array}{l}0 \\
0 \\
0 \\
0 \\
0\end{array}$ & 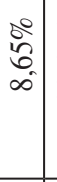 & 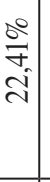 & $\begin{array}{l}80 \\
0 \\
0 \\
0\end{array}$ & 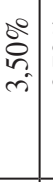 & 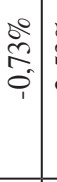 & 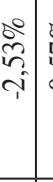 & $\begin{array}{l}0 \\
\vdots \\
i \\
0 \\
i\end{array}$ & 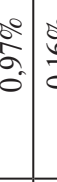 & : & 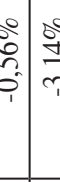 & 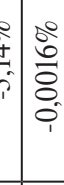 & $\begin{array}{l}\text { ô } \\
\text { ते } \\
+\end{array}$ & $\left|\begin{array}{c}0 \\
0 \\
0 \\
-1\end{array}\right|$ & $\begin{array}{l}80 \\
0 \\
0 \\
0\end{array}$ & $\begin{array}{l}\text { बे. } \\
\text { cे } \\
1\end{array}$ & \\
\hline & 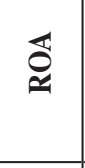 & $\begin{array}{l}0 \\
0 \\
0 \\
0\end{array}$ & 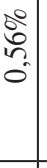 & $\begin{array}{l}0 \\
0 \\
0 \\
0 \\
0\end{array}$ & $\begin{array}{l}0 \\
0 \\
0 \\
0 \\
0\end{array}$ & $\begin{array}{l}0 \\
0 \\
0 \\
1 \\
1\end{array}$ & $\begin{array}{l}0 \\
0 \\
0 \\
0 \\
1\end{array}$ & $\begin{array}{l}80 \\
0 \\
0 \\
0 \\
1\end{array}$ & $\begin{array}{c}0 \\
0 \\
o \\
0 \\
0\end{array}$ & 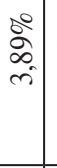 & $\begin{array}{l}0 \\
0 \\
0 \\
i \\
\text { in }\end{array}$ & $\begin{array}{l}0 \\
0 \\
0 \\
0 \\
1\end{array}$ & 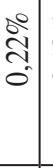 & $\begin{array}{l}0 \\
\infty \\
0 \\
0\end{array}$ & \begin{tabular}{c}
0 \\
\multirow{1}{*}{} \\
\hdashline
\end{tabular} & 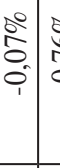 & \begin{tabular}{l|l}
0 \\
0 \\
0 \\
0
\end{tabular} & \begin{tabular}{l|l}
0 \\
0 \\
0 \\
0 \\
0
\end{tabular} & $\begin{array}{ll}0 \\
0 \\
0 \\
0\end{array}$ & 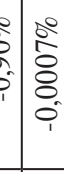 & 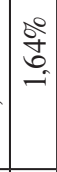 & 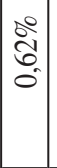 & $\begin{array}{l}0 \\
\vdots \\
0 \\
0 \\
0\end{array}$ & $\begin{array}{l}00 \\
0 \\
0 \\
0 \\
1\end{array}$ & \\
\hline & 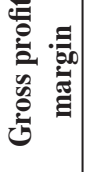 & $\begin{array}{l} \\
0 \\
0 \\
0 \\
0\end{array}$ & 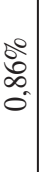 & $\begin{array}{l}0 \\
0 \\
\infty \\
\infty \\
\infty \\
1\end{array}$ & $\begin{array}{c}0 \\
0 \\
0 \\
-1 \\
-1\end{array}$ & \begin{tabular}{l}
0 \\
\multirow{2}{0}{} \\
0 \\
0 \\
1
\end{tabular} & $\begin{array}{c}0 \\
0 \\
0 \\
0 \\
1\end{array}$ & $\begin{array}{l}80 \\
0 \\
\circ \\
+ \\
1\end{array}$ & $\begin{array}{l}0 \\
\text { ठ0. } \\
0\end{array}$ & $\begin{array}{c}0 \\
\vdots \\
\vdots \\
i \\
i\end{array}$ & $\begin{array}{l}\stackrel{0}{0} \\
\underset{6}{-} \\
-\end{array}$ & $\begin{array}{l}0 \\
0 \\
0 \\
0 \\
1\end{array}$ & $\begin{array}{l}\text { ڤ̊ } \\
\text { ते } \\
\text { s. }\end{array}$ & 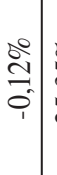 & 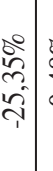 & 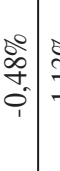 & 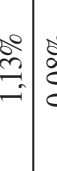 & $\begin{array}{c}0 \\
\vdots \\
0 \\
0 \\
0\end{array}$ & $\begin{array}{lll}0 & 0 \\
2 & 0 \\
1 & 7\end{array}$ & 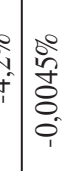 & $\begin{array}{l}0 \\
\tilde{\delta} \\
\text { i }\end{array}$ & $\mid \begin{array}{c}0 \\
\vdots \\
\vdots \\
0 \\
0\end{array}$ & $\begin{array}{l}0 \\
0 \\
0 \\
0 \\
0\end{array} \mid$ & $\begin{array}{l}\stackrel{0}{\prime} \\
\rightarrow\end{array}$ & \\
\hline \multirow{5}{*}{ 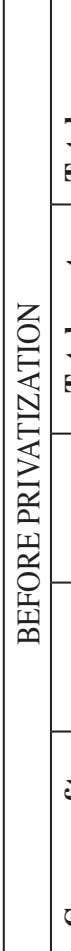 } & 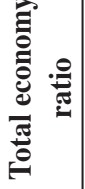 & $\left|\begin{array}{c}\vec{\infty} \\
0 \\
0\end{array}\right|$ & $\stackrel{\vec{\sigma}}{-}$ & $\begin{array}{l}2 \\
0 \\
0\end{array}$ & $\begin{array}{l}\text { ते } \\
\text { ठे }\end{array}$ & $\begin{array}{l}0 \\
0 \\
0\end{array}$ & $\begin{array}{l}2 \\
\infty \\
0\end{array} \mid$ & $\begin{array}{l}\infty \\
\stackrel{2}{0} \\
0\end{array}$ & $\begin{array}{c}\tilde{\sigma} \\
- \\
-\end{array}$ & $\stackrel{2}{=}$ & $\underset{-}{-}$ & ڤે & $\stackrel{8}{-}$ & $\begin{array}{l}\circ \\
\circ \\
\circ\end{array}$ & 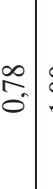 & $\stackrel{8}{-}$ & $\begin{array}{l}2 \\
\vdots \\
0\end{array}$ & $\begin{array}{c}2 \\
0\end{array}$ & $\stackrel{0}{\circ}$ & $\begin{array}{l}v_{0} \\
= \\
=\end{array}$ & $\stackrel{ \pm}{=}$ & $\underset{-}{\stackrel{0}{0}}$ & $\stackrel{8}{-}$ & $\frac{2}{0}$ & \\
\hline & 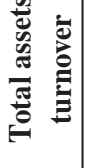 & $\frac{9}{0}$ & $\frac{0}{0}$ & $\begin{array}{l}\overline{0} \\
0\end{array}$ & $\begin{array}{l}8 \\
0 \\
0\end{array}$ & $\begin{array}{l}2 \\
0 \\
0 \\
0\end{array}$ & \begin{tabular}{l|}
$\infty$ \\
0 \\
0
\end{tabular} & $=$ & 命 & $\stackrel{\sim}{\beth}$ & $\begin{array}{l}n \\
\tilde{b} \\
i\end{array}$ & $\begin{array}{l}\infty \\
\stackrel{0}{0}\end{array}$ & $\begin{array}{l}\text { के } \\
\text { i }\end{array}$ & $\begin{array}{l}8 \\
0 \\
0\end{array}$ & ?ै & $\begin{array}{l}3 \\
\infty \\
0 \\
0\end{array}$ & ? & \begin{tabular}{ll|l}
0 \\
0 \\
0
\end{tabular} & בa & $\delta_{0}^{\circ}$ & $\begin{array}{l}n \\
i \\
i\end{array}$ & 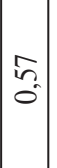 & ठे. & $\begin{array}{l} \pm \\
0 \\
0\end{array}$ & \\
\hline & $\begin{array}{l}\text { rid } \\
\approx\end{array}$ & $\left|\begin{array}{l}0 \\
\vdots \\
0 \\
0 \\
1\end{array}\right|$ & $\begin{array}{l}\stackrel{0}{0} \\
0 \\
0\end{array}$ & $\begin{array}{l}00 \\
\vdots \\
0 \\
0\end{array}$ & $\begin{array}{l}0 \\
0 \\
0 \\
0 \\
0\end{array}$ & 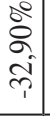 & $\begin{array}{l}0 \\
0 \\
0 \\
0 \\
1\end{array}$ & $\begin{array}{l}0 \\
0 \\
0 \\
0 \\
0 \\
1\end{array}$ & $\begin{array}{l}0 \\
\tilde{n} \\
\tilde{o} \\
\vdots\end{array}$ & $\begin{array}{l}\stackrel{0}{0} \\
\stackrel{2}{0} \\
\end{array}$ & $\begin{array}{l}\frac{0}{5} \\
\sigma_{0}\end{array}$ & 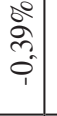 & 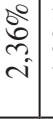 & 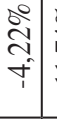 & 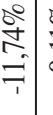 & 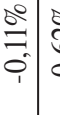 & 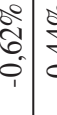 & 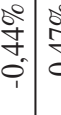 & 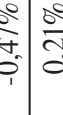 & $\begin{array}{c}0 \\
0\end{array}$ & $\frac{8}{m}$ & 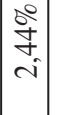 & $\begin{array}{l}\stackrel{0}{\vec{f}} \\
\stackrel{0}{0}\end{array}$ & 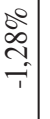 & \\
\hline & 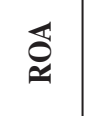 & $\begin{array}{l}0 \\
0 \\
0 \\
0 \\
1\end{array} \mid$ & 告 & \begin{tabular}{l|}
0 \\
0 \\
0 \\
0 \\
\end{tabular} & $\begin{array}{l}0 \\
0 \\
0 \\
0 \\
1\end{array}$ & 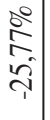 & $\begin{array}{l}0 \\
0 \\
0 \\
0 \\
1\end{array}$ & $\begin{array}{l}0 \\
2 \\
0 \\
0 \\
1\end{array}$ & $\begin{array}{l}0 \\
\vec{\sigma} \\
0 \\
0\end{array}$ & $\begin{array}{l}0 \\
\text { ¿ें } \\
\text { ì }\end{array}$ & \begin{tabular}{c|}
0 \\
0 \\
$\infty$ \\
0 \\
0
\end{tabular} & $\begin{array}{l}0 \\
0 \\
0 \\
0 \\
1\end{array}$ & 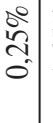 & $\begin{array}{l}0 \\
8 \\
0 \\
-1\end{array}$ & 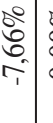 & 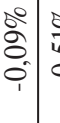 & 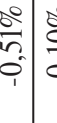 & \begin{tabular}{c|c}
0 \\
\hdashline \\
0 \\
\\
\end{tabular} & $\begin{array}{l}0 \\
0 \\
0 \\
0 \\
\end{array}$ & $\frac{8}{\stackrel{0}{c}}$ & $\begin{array}{l}\stackrel{0}{\lambda} \\
\text { तु }\end{array}$ & $\mid \begin{array}{l}0 \\
\stackrel{2}{-} \\
=\end{array}$ & $\begin{array}{l}0 \\
0 \\
\\
0 \\
0\end{array}$ & $\begin{array}{l}0 \\
2 \\
\\
0 \\
1\end{array}$ & \\
\hline & 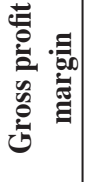 & $\underset{1}{\stackrel{0}{7}}$ & $\begin{array}{c}0 \\
0 \\
0 \\
0 \\
0 \\
0\end{array}$ & 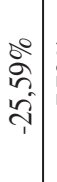 & $\begin{array}{l}\stackrel{2}{2} \\
\stackrel{2}{*}\end{array}$ & 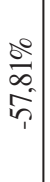 & $\begin{array}{l}\frac{0}{2} \\
\hat{N} \\
0 \\
1\end{array}$ & 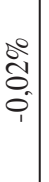 & $\begin{array}{l}\stackrel{0}{0} \\
\text { - }\end{array}$ & $\begin{array}{l}\frac{80}{F} \\
\dot{f}\end{array}$ & $\begin{array}{l}0 \\
0 \\
0 \\
0 \\
0\end{array}$ & 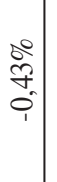 & $\begin{array}{l}\text { o̊ } \\
\text { oे } \\
0\end{array}$ & 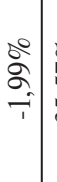 & 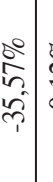 & \begin{tabular}{l}
0 \\
$\stackrel{0}{0}$ \\
\hdashline \\
0 \\
1
\end{tabular} & ç & $\begin{array}{c}0 \\
\vdots \\
\vdots \\
\end{array}$ & $\begin{array}{l}b^{\circ} \\
\\
\end{array}$ & $\begin{array}{l}0 \\
0 \\
i=0\end{array}$ & $\frac{0}{\sigma}$ & $\begin{array}{l}\stackrel{0}{2} \\
\stackrel{2}{i} \\
\text { in }\end{array}$ & 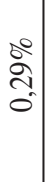 & 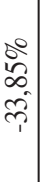 & \\
\hline & & $\dot{\imath}$ & $\vec{\sim}$ & $\stackrel{\dot{\sim}}{\sim}$ & ते & $\dot{\varnothing}$ & $\dot{m}$ & लें & $\dot{m}$ & $\dot{m}$ & mे & $\dot{m}$ & $\dot{m}$ & $\dot{m}$ & लें & $\dot{q}$ & $\dot{\forall} ?$ & ঙ่ & $\dot{f}$ & $\dot{f}$ & $\dot{f}$ & $\dot{f}$ & 字 & $\dot{q}$ & \\
\hline
\end{tabular}


Before the interpretation of the results (Table 5) it should be noted that most of the observed companies in the period before the privatization were operating with a loss, and when using the term "successful" in most cases it is about reducing losses, and only in some cases, it is about transition from losses to profit. The observed period is a period of three years after privatization, which is objectively short to change a company's losing position into profitable company.

Before the implementation of the analysis it should be noted that of the total number of observed privatized companies, 22 of them ended up in bankruptcy or liquidation by the end of 2014.Eight companies received criminal or misdemeanour applications due to the non-implementation of privatization procedures under laws and procedures, but the business result cannot be related to this, because the companies had both incurred criminal and misdemeanour registrations at the same time, the ones with better and worse business results.

Of the 50 observed companies, 21 of them operated poorly in private ownership, $42 \%$ of the privatized companies did not have any improvement, one or two of the possible five improvements in the value of the analysed financial indicators was noted in the period of three years after privatization compared to the period before privatization, $46 \%$ of the analysed companies (23) had more successful average results - increase was in the value of four or five indicators over a period of three years after privatization. A partial increase in business performance, i.e. higher value three of the five indicators had 6 companies, or $12 \%$ of them. By considering the structure of 23 companies that had a more successful business after privatization, it can be said that 12 companies achieved the growth in four out of the five observed analysed indicators, while 11 companies achieved the growth of all five indicators.

It is important to point out that only five companies after the change of ownership before privatization succeeded in going from the loss into profit, while the two companies were gaining profits even before privatization, and new owners succeeded in gaining profits over the years after privatization. The analysis of the remaining four loss-making companies in the period before privatization showed that new owners managed to reduce the loss but did not make a turn to profit.

If the given results are analysed at the level of the selected financial indicators (figure 3 ) it is concluded that the ratio of total assets turnover was increased by $68 \%$ for the largest number of observed companies, followed by an indicator of economy that improved by $58 \%$ of enterprises, while the smallest number of companies managed to improve the value of return on equity $(48 \%)$. 


\section{Figure 3.}

\section{PERCENTAGE OF IMPROVEMENT OF THE VALUE OF ANALYSED INDICATORS IN THE PERIOD AFTER PRIVATIZATION}

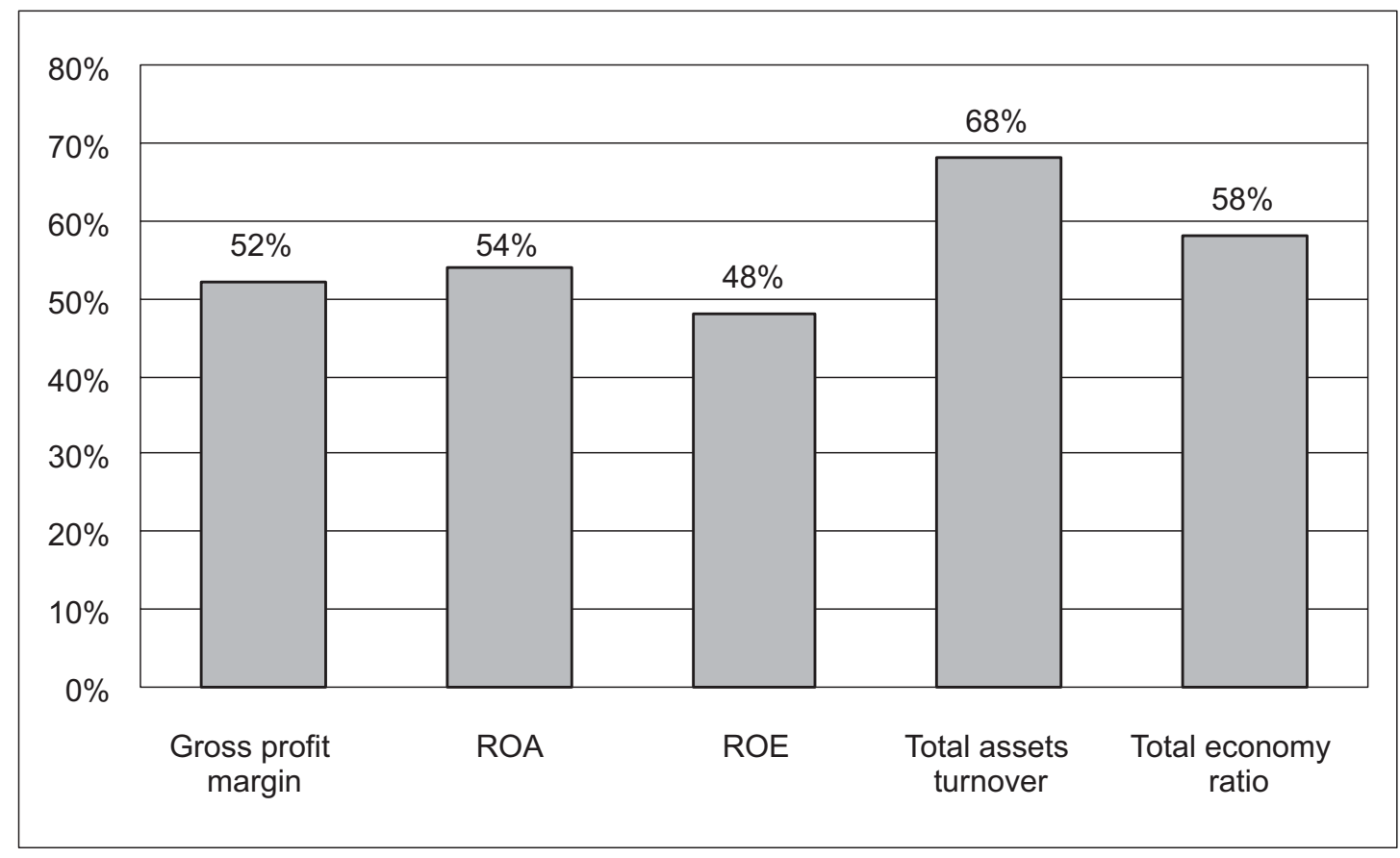

Source: Creation of authors

As indicators of activity point to the speed of property circulation in business flows, it can be said that the majority of businesses with moving to private property have managed to increase the success of using assets to generate revenue. The ratio of revenues and expenses has improved more than half of the observed companies in the period after privatization, which suggests that the indicators of economy were better in most companies.

Indicators of profitability are the most important parts of the financial analysis and are commonly used to evaluate business performance. Relations between profit and sales and investments have been observed. The gross profit margin points on the ability of management to run a business. Any increase in the value of this indicator is judged to be favourable, and the decrease in value indicates difficulties in the business of the company. The results of the analysis showed that $52 \%$ of the observed companies managed to increase the value of this indicator, however, as already mentioned above, in most cases the negative value was just reduced and it was very rare that there was a trend of transition to a positive result. 
Return on Total Assets (ROA) is an indicator of the success of using assets in making a profit. This indicator varies greatly depending on the industry or business the company is engaged in. The analysis showed that $54 \%$ of companies realized an increase in the rate of return on total assets in the post-privatization period.

The smallest increase have been recognised in ROE (return on equity). $48 \%$ of the observed companies managed to improve the profitability of capital in the post-privatization period compared to the pre-privatization period.

Summing up all the above, it can be concluded that 27 companies failed or partially managed to increase the performance of their business, which is $54 \%$ of the analysed companies, and based on such results cannot be proven that the performance ofall privately-owned observed companies is increased. However, as almost half of the observed companies were still more successful in a three-year period after privatization, the hypothesis could be partially confirmed.

\section{Conclusion}

Privatisation processes have begun in last decades of last century. Many countries recognized the advantages of privatisation in the form of financial goals such as increasing state budget, lowering indebtedness and strengthening market economy. Furthermore, the presumption of privatisation is that private ownership is better for profitability of a company. Private ownership also indicates better business management and as a result, there is higher chance that private company will perform better. On the other hand, taxpayers' money could be spend on significant activities in public sector without the need for financing inefficient business operations. Taking into consideration abovementioned, the goal of the paper was to investigate the impact of privatisation process on business performance on example of the companies in the Republic of Croatia. The base for the selection of privatised companies was the state audit office report on the conducted state audit of privatisation in the Republic of Croatia. The reason for such selection is in fact that there isn't sufficient available data on financial reporting public and private companies which operates within the same industry. This cause some research restriction which is related to the time and environment of privatisation. The research results indicate that there is a difference between the business performance of companies prior and after privatisation. It has to be stressed that interesting information could be gained provided business performance analysis was done in the period after privatisation which would cover longer time span. This can be a suggestion for some further research. 


\section{References:}

Akrap V., et.al (2009) Državna revizija.Zagreb: Masmedia.

Annual financial statements of the selected companies, the Register of annual financial statements, FINA.

Astami E.W., Tower G., Rusmin R. and Neilson J. (1992) The effect of privatisation on performance of state owned enterprises in Indonesia. Asian Review of Accounting, Volume 18, Issue 1, Emerald Group Publishing Limited, pp.5-19. Available at: https://doi.org/10.1108/13217341011045971

Carslaw, C. A. and Mills, J. R. (1991)Developing Ratios for Effective Cash Flow Statement Analysis. Journal of Accountancy, 11/1991. New York.

Čulo M. (2912) Analiza kreditne sposobnosti trgovačkih društava od posebnog javnog interesa. Zagreb: Institut za javne financije.

Državni ured za reviziju (2007) Izvješće o radu na provedbi pretvorbe i privatizacije. Available at:http://www.revizija.hr/hr/izvjesca/revizije-pretvorbe-i-privatizacije

Estrin, S., Bakanova, M., Pelipas, I. and Pukovich, S. (2006) The effects of privatization on company performance in Belarus. Available at:http://personal.lse.ac.uk/estrin/ Publication\%20PDF's/enterpriseresutructuringinbelarus.pdf

ISSAI (1998) ISSAI 5210 Guidelines on Best Practice for the Audit of Privatisation. Available at:www.issai.org

Kawabata, E. (2006) Contemporary Government Reform in Japan: The Dual State in Flux, Pallgrave Macmillan

Simeon, D., Murrell P. (2002) Enterprise Restructuring in Transition: A Quantitative Survey. Journal of Economic Literature, 40(3): 739-792. Megginson, W, L., Netter, J. M. (2001.) "From State to Market: A Survey of Empirical Studies on Privatization.” Journal of Economic Literature, 39(2): 321-389.

Vizek, M. (2015) Poslovanje javnih poduzeća i njihov značaj za ekonomsku aktivnost u RH, Zagrebački ekonomski forum.

Vuković, D. (2016)Uloga državne revizije u povećanju učinkovitosti i uspješnosti javnih poduzeća (Doctoral dissertation). University of Zagreb. Faculty of Economics and Business.

Zakon o privatizaciji (1996) Narodne novine 21/1996.

Žager, K.; Mamić Sačer, I.; Sever, S.; Ježovita, A. and Žager. L. (2017) Analiza financijskih izvještaja - načela, postupci, slučajevi. Zagreb: Hrvatska zajednica računovođa i financijskih djelatnika Zagreb. 
D. VUKOVIĆ, I. MAMIĆ SAČER: The impact of privatisation process on business performance of the selected... EKONOMSKI PREGLED, 69 (6) 621-637 (2018)

\title{
UTJECAJ PROCESA PRIVATIZACIJE NA USPJEŠNOST POSLOVANJA ODABARANIH PODUZEĆA U REPUBLICI HRVATSKOJ
}

\begin{abstract}
Sažetak
Značajniji procesi privatizacije počeli su krajem prošlog stoljeća. Sam početak i trajanje privatizacije specifično je za svaku zemlju. Mnoge zemlje prepoznale su brojne prednosti privatizacije u obliku ostvarivanja financijskih ciljeva kao što su primjerice povećanje državnog proračuna, smanjenje zaduženosti te u konačnici i jačanje gospodarstva. Nerijetko se naglašava kako je privatno vlasništvo pretpostavka ostvarivanja bolje uspješnosti poslovanja pojedinog poduzeća, stoga je temeljna svrha ovog istraživanja bila utvrditi utjecaj procesa privatizacije na uspješnost poslovanja odabranih poduzeća u Republici Hrvatskoj. Metodologija ovog istraživanja obuhvaća dva temeljna dijela. U prvom dijelu provodi se teoretska analiza utjecaja privatizacije na uspješnost poslovanja. Pored toga, provedene su dvije empirijske analize na odabranim poduzećima u Republici Hrvatskoj. Poznato je da je podloga za oblikovanje financijskih izvještaja upravo računovodstveni informacijski sustav poslovnog subjekta u koji se unose i evidentiraju brojni poslovni događaji u skladu s pravilima ove struke. Tako pripremljeni financijski izvještaji koriste se za ocjenu uspješnosti poslovanja i financijskog položaja poduzeća. Iz tog razloga, provedena analiza temelji se na financijskim izvještajima odabranih poduzeća a sama analiza je oblikovana u dva smjera. Prva analiza provedena je na temelju odabranih financijskih izvještaja prije i nakon procesa privatizacije uz pomoć analize kvartila. Financijski pokazatelji na osnovi kojih je provedena ova analiza jesu: bruto marža profita, povrat na imovinu, povrat na glavnicu, koeficijent obrta ukupne imovine i pokazatelj ekonomičnosti ukupnog poslovanja. S druge strane, kako bi se dobio pojedinačni utjecaj procesa privatizacije na poduzećima obuhvaćenim analizom provedena je dublja analiza pokazatelja. U tom kontekstu, izračunati su odabrani financijski pokazatelji na istom istraživačkom uzorku te su uspoređeni rezultati prije i poslije privatizacije zasebno za svako promatrano poduzeće. Rezultati istraživanja dobiveni pomoću analize kvartila upućuju na postojanje razlike u uspješnosti poslovanja analiziranih poduzeća prije i nakon procesa privatizacije i prema njima privatna poduzeća su pokazala veću razinu uspješnosti nego državna - javna poduzeća. Međutim, rezultati dobiveni na osnovi pojedinačne analize tih istih poduzeća samo djelomično potvrđuju hipotezu da su privatna poduzeća uspješnija nego javna.
\end{abstract}

Ključne riječi: uspješnost poslovanja, privatizacija, državna poduzeća, privatna poduzeća Hrvatska 